\title{
Kristina. Pemodelan Sistem Informasi Pendataan Warga Dan Biaya Operasional Lingkungan Pada Komplek Perumahan HarmoniPark Berbasis Zachman Framework \\ PEMODELAN SISTEM INFORMASI PENDATAAN WARGA DAN BIAYA OPERASIONAL LINGKUNGAN PADA KOMPLEK PERUMAHAN HARMONI PARK BERBASIS ZACHMAN FRAMEWORK
}

\author{
Kristina \\ Program Studi/Jurusan Sistem Informasi \\ Sekolah Tinggi Manajemen Informatika dan Komputer Widya Dharma \\ Jl. HosCokroaminoto Gang Palem No. 16, Kota Pontianak \\ Email: vinalim@yahoo.com
}

\begin{abstract}
Abstraksi
Jumlah warga dan jumlah iuran yang banyak harus dikelola dengan sistematis sehingga setiap transaksi bisa terdata dengan baik serta mudah diakses. Jumlah warga yang banyakdikelompokkan dengan istilah Rukun Tetangga (RT). Setiap RT akan dikepala oleh seorang kepala RT. Kepala RT harus memiliki sebuah sistem yang jelas dalam mendata warga dan iuran yang dikelola sehingga mampu memberikan pertanggungjawaban yang jelas kepada warga itu sendiri. Rukun Tetangga (RT) merupakan tingkat pemerintahan yang paling bawah dalam struktur pemerintahan. Kompleks Harmoni Park memiliki warga sebanyak 240 KK (kepala keluarga). Selain itu Kompleks Harmoni Park memiliki unit pengolahan air mandiri karena PDAM belum sampai pada kompleks tersebut. Dalam mengelola air, Kompleks Harmoni Park memiliki mesin khusus dan tim khusus untuk merawat mesin tersebut.

Selama masa pengolahan air mandiri tersebut, maka biaya pemakaian, biaya, biaya perawatan dan biaya operasional tim dibebankan kepada penghuni kompleks. Peendataan warga dan pengelolaan iuran masih dilakukan secara konvensional atau manual sehingga pendataan warga dan pengelolaan iuran warga mempunyai banyak kekurangan seperti kesalahan pencatatan, proses pencarian data yang lama maupun dalam proses pembuatan laporan. Masalah ini menjadi dasar dibutuhkan suatu sistem pengarsipan yang baik serta aplikasi yang dapat membantu para pengurus RT setempat.

Pengumpulan data dilakukan menggunakan metode observasi dan wawancara ntuk menunjang perancangan aplikasi pendataan warga dan biaya operasional komplek perumahan Harmoni Park. Adapun alat yang digunakan dalam pemodelan sistem informasi adalah Zachman Framework. Tujuan dari perancangan aplikasi pendataan warga dan biaya operasional adalah untuk menghasilkan sebuah sistem informasi pengelolaan data warga dan biaya operasional yang lebih cepat, efektif, efisien dan transparan pada Komplek Perumahan Harmoni Park.
\end{abstract}

Kata kunci: Sistem Informasi, Pendataan Warga, Biaya Operasional, Pengelolaan Iuran, Zachman Framework

\section{Pendahuluan}

Kemajuan teknologi informasi sangat berdampak pada pemanfaatan teknologi informasi yang sangat besar pada suatu organisasi seperti perusahaan, instansi-instansi, ataupun bidang lainnya. Pemanfaatan teknologi informasi diharapkan mampu meningkatkan kinerja perusahaan atau yang lainnya. Tetapi yang menjadi kendala adalah biaya investasi pengembangan sistem informasi cukup besar dan bersifat keuntungan intangible. Keuntungan intangible adalah keuntungan yang didapat dan diukur dari adanya peningkatan kinerja dan tidak bersifat langsung berupa materi. Hal ini berarti bahwa ketika membangun sebuah sistem informasi harus melalui sebuah konsep perancangan yang matang. Konsep perancangan sebuah sistem informasi bisa dilakukan dengan menerapkan Zachman Framework ketika menjelaskan sebuah model sistem informasi.

Investasi teknologi informasi yang gagal terjadi karena tidak matangnya organisasi yang meliputi seluruh elemen dalam merencanakan pembangunan sistem informasi. Perencanaan yang dilakukan hanya ditinjau dari kebutuhan jangka pendek itupun tidak menyeluruh hanya bagian-bagian atau fungsi-fungsi tertentu saja yang dibutuhkan pada saat itu oleh organisasi yang bersangkutan. Komplek Harmoni Park merupakan sekian banyak dari kompleks perumahan yang terdapat di kompleks perumahan kota Pontianak. Kompleks ini memiliki kurang lebih dari 240 unit rumah, yang mana untuk sementara ini dibentuk menjadi 1 Rukun Tetangga (RT) yaitu RT. 004 di bawah naungan RW 10. Saat ini pendataan warga kompleks didata oleh masing- 


$$
\begin{array}{c|l}
\text { Jurnal Sains Komputer dan Teknologi Informasi } & \text { Page } \\
\text { e-issn: 2655-7460. Volume } 2 \text { No.1, November 2019 } & 55-62
\end{array}
$$

masing RT, baik warga sebagai pemilik rumah ataupun yang sewa.

Setiap ada warga pendatang baik yang membeli rumah di kompleks tersebut ataupun yang akan menyewa diharapkan lapor ke ketua RT, jika warga yang bersangkutan dalam waktu 24 jam tidak melapor, maka pengurus RT akan mengunjunginya untuk didata. Selama ini pendataan warga oleh RT dengan cara konvensional atau manual, yaitu warga diharuskan mengisi formulir, dan untuk warga yang menyewa diharuskan melampirkan photocopyKTP dan Kartu Keluarga atau identitas lainnya. Formulir yang sudah diisi diarsip begitu saja oleh ketua RT.

Di lingkungan kompleks ini warga diwajibkan untuk membayar iuran yang dikelola oleh RT masing-masing. Baik warga penghuni rumah sendiri maupun yang menyewa. Sistem pembayarannya, warga bisa menyampaikannya ke bendahara RT secara langsung. Bagi warga yang menunggak atau terlambat dalam melakukan pembayaran,pihak RT akan mendatangi rumah warga melalui securityuntuk menagih.

Diharapkan dengan adanya aplikasi ini, pendataan warga dapat dikelola secara terorganisir, dan terhindar dari redudansi data. Dengan adanya sistem ini diharapkan warga dapat mengetahui mengenai status pembayaran iurannya, sehingga warga dapat kooperatif untuk membayar kewajibannya tanpa harus ditagih oleh security. Serta warga dapat mengetahui alokasi dana iuran yang mereka kumpulkan dalam setiap periodenya tersebut digunakan untuk apa. Sehingga ada transparansi dana iuran antara pihak pengurus RT dengan warganya. Jumlah warga dan jumlah iuran yang banyak harus dikelola dengan sistematis sehingga setiap transaksi bisa terdata dengan baik serta mudah diakses. Jumlah warga yang banyakdikelompokkan dengan istilah Rukun Tetangga (RT). Setiap RT akan dikepala oleh seorang kepala RT. Kepala RT harus memiliki sebuah sistem yang jelas dalam mendata warga dan iuran yang dikelola sehingga mampu memberikan pertanggungjawaban yang jelas kepada warga itu sendiri. Rukun Tetangga (RT) merupakan tingkat pemerintahan yang paling bawah dalam struktur pemerintahan. Kompleks Harmoni Park memiliki warga sebanyak 240 KK (kepala keluarga). Selain itu Kompleks Harmoni Park memiliki unit pengolahan air mandiri karena PDAM belum sampai pada kompleks tersebut. Dalam mengelola air, Kompleks Harmoni Park memiliki mesin khusus dan tim khusus untuk merawat mesin tersebut.

Selama masa pengolahan air mandiri tersebut, maka biaya pemakaian, biaya, biaya perawatan dan biaya operasional tim dibebankan kepada penghuni kompleks. Peendataan warga dan pengelolaan iuran masih dilakukan secara konvensional atau manual sehingga pendataan warga dan pengelolaan iuran warga mempunyai banyak kekurangan seperti kesalahan pencatatan, proses pencarian data yang lama maupun dalam proses pembuatan laporan. Masalah ini menjadi dasar dibutuhkan suatu sistem pengarsipan yang baik serta aplikasi yang dapat membantu para pengurus RT setempat.

\section{METODOLOGI PENELITIAN}

\subsection{Metode Penelitian}

Menurut William Chang (2014:27) yaitu “ metode penelitian mencakup metode observasional yang mengadakan pengamatan dengan seksama dan kritis. Metode ini dapat menyoroti kekhasan dari objek penelitian (cross sectional). Sehingga dalam penelitian menggunakan metode deskriptif yaitu penelitian yang dilakukan dengan studi kasus dan pengamatan langsung terhadap objek penelitian yang berhubungan dengan permasalahan yang dibahas serta menggambarkan secara narasi bagaimana model tersebut dibangun.

\subsection{Teknik Pengumpulan Data}

a) Metode Observasi

Observasi adalahsuatu cara untuk mengumpulkan data penelitian dengan mempunyai sifat dasar naturalistik yang berlangsung dalam konteks natural, pelakunya berpartisipasi secara wajar dalam interaksi.Sehingga dapat disimpulkan bahwa Observasi adalah teknik pengumpulan data yang dilakukan dengan cara mempelajari dan mengadakan pengamatan secara langsung kedalamsuatu lingkungan masyarakat untuk mendapatkan bukti-bukti yang dapat mendukung dan melengkapi suatu pengumpulan data.

b) Metode Wawancara

Wawancara adalah suatu kegiatan yang dilakukan untuk mendapatkan informasi secara langsung dengan mengungkapkan pertanyaanpertanyaan pada para responden. wawancara bermakna berhadapan langsung antara interview dengan responden, dan kegiatannya dilakukan secara lisan. Cara yang umum dan ampuh untuk memahami suatu keinginan atau kebutuhan.wawancara adalah teknik pengambilan data melalui pertanyaan yang diajukan secara lisan kepada responden.Sehingga dapat ditarik kesimpulan bahwa wawancara merupakan suatu teknik pengumpulan data berupa sebuah tanya jawab yang dapat dilakukan 
Kristina. Pemodelan Sistem Informasi Pendataan Warga Dan Biaya Operasional Lingkungan

Pada Komplek Perumahan HarmoniPark Berbasis Zachman Framework

secara langsung antara pengembang dan pihak yang berhubungan langsung dengan sistem tersebut termasuk warga.

\section{LANDASAN TEORI}

Adapun teori-teori yang mendukung dalam penelitian ini adalah sebagai berikut:

\subsection{Data}

Menurut Yakub (2012:5): "Data adalah deskripsi tentang benda, kejadian, aktivitas, dan transaksi, yang tidak mempunyai makna atau tidak berpengaruh secara langsung kepada pemakai." Sedangkan menurut Siagian sebagaimana dikutip oleh Yulianto (2018:35):"Data merupakan suatu bahan baku yang harus diolah sedemikian rupa sehingga berubah sifatnya menjadi informasi."

Dari beberapa pendapat diatas, dapat disimpulkan bahwa data merupakan sekumpulan fakta-fakta yang belum memiliki arti bagi penerimanya sehingga harus diolah sedemikian rupa agar menjadi sebuah informasi yang dapat dimengerti.

3.2. Informasi

Menurut Hutahean (2014:9): "Informasi adalah data yang diolah menjadi bentuk yang lebih berguna dan lebih berarti bagi penerimanya". Sedangkan menurut Anggraeni dan Irviani(2017:13): "Informasi adalah sekumpulan data/fakta yang diorganisasikan atau diolah dengan cara tertentu sehingga mempunyai arti bagi penerimanya."

Dari beberapa pendapat diatas, dapat disimpulkan bahwa informasi merupakan sekumpulan data yang sudah diolah sedemikian rupa sehingga menghasilkan informasi yang memiliki nilai bagi penerimanya.

\subsection{Sistem}

Menurut Tohari (2014:2): "Sistem adalah kumpulan atau himpunan dari unsur atau variabel-variabel yang saling terkait, saling berinteraksi, dan saling tergantung satu sama lain untuk mencapai tujuan."Menurut Sutabri (2012:6): "Sistem adalah sekelompok unsur yang erat hubungannya satu dengan yang lain, yang berfungsi bersama-sama untuk mencapai tujuan tertentu."

Menurut Jogianto sebagaimana dikutip oleh Hutahean(2014:1):

"Sistem adalah kumpulan dari elemen-elemen yang berinteraksi untuk mencapai suatu tujuan tertentu. Sistem ini menggambarkan suatu kejadian-kejadian dan kesatuan yang nyata adalah suatu objek nyata, seperti tempat, benda, dan orang-orang yang betul ada dan terjadi."Dari beberapa pendapat diatas, dapat disimpulkan bahwa sistem adalah sekelompok elemen yang saling terkait dalam mencapai suatu tujuan tertentu.

3.4. Sistem Informasi

Menurut Anggraeni dan Irviani (2017:2):

"Sistem Informasi merupakan suatu kombinasi teratur dari orang-orang, hardware, software, jaringan komunikasi dan sumber daya data yang mengumpulkan, mengubah, dan menyebarkan informasi dalam sebuah organisasi." Menurut Nash sebagaimana dikutip oleh Djahir(2014:14): "Sistem informasi adalah kombinasi dari manusia, fasilitas atau alat teknologi, media, prosedur dan pengendalian yang bermaksud menata jaringan komunikasi yang penting, proses atas transaksi-transaksi tertentu dan rutin, membantu manajemen dan pemakai intern dan ekstern dan menyediakan dasar pengambilan keputusan yang tepat". Dari beberapa pendapat diatas, dapat disimpulkan bahwa sistem informasi merupakan kombinasi dari manusia, fasilitas atau alat teknologi, media, prosedur dan pengendalian yang terlibat dalam suatu kegiatandan melibatkan serangkaian proses dalam membantu pengambilan keputusan yang digunakan untuk mencapai suatu tujuan

\subsection{Pendataan}

Pengertian pendataan menurut Kamus Besar Bahasa Indonesia, menyatakan bahwa : "Pendataan adalah kegiatan mencatat dan memasukan data kedalam sebuah catatan"[2001:314]. Sehingga sesuai dengan konteks pembahasan kali ini pendataan berarti pencatatan dan memasukan data diri warga komplek perumahan Harmoni Park. Hal ini guna sebagai masukan ke dalam sistem pencatatan iuran warga.

3.6. Iuran

Iuran warga merupakan sejumlah uang yang dikumpulkan masyarakat di sebuah pemukiman untuk keperluan lingkungan maupuan kebutuhan RT/RW.RT merupakan lembaga kemasyarakatan yang menjadi "perpanjangan tangan" pemerintah pusat pada warga yang tinggal di kawasan tertentu.Hal ini pun telah dituangkan dalam Pasal 1 angka 1 Permendagri 5/2007 yang berbunyi: "Lembaga kemasyarakatan atau yang disebut dengan nama lain adalah lembaga yang dibentuk oleh 


$$
\begin{array}{c|l}
\text { Jurnal Sains Komputer dan Teknologi Informasi } & \text { Page } \\
\text { e-issn: 2655-7460. Volume } 2 \text { No.1, November 2019 } & 55-62
\end{array}
$$

masyarakat sesuai dengan kebutuhan dan merupakan mitra pemerintah desa dan lurah dalam memberdayakan masyarakat."

\subsection{Komplek Perumahan}

Perumahan adalah sekelompok rumah atau bangunan lainnya yang dibangun bersamaan sebagai sebuah pengembangan tunggal. Bentuknya bervariasi di negara-negara manapun. Perumahan biasanya dibangun oleh seorang kontraktor tinggal dengan hanya beberapa gaya rancangan rumah atau bangunan, sehingga penampilannya menjadi seragam

3.8. Diagram UML

Unified Modeling Language (UML)

Menurut Mulyani (2016:35): “UML adalah sebuah teknik pengembangan sistem yang menggunakan bahasa grafis sebagai alat untuk pendokumentasian dan melakukan spesifikasi pada sistem".

Menurut Sugiarti (2013:38-81):

"Unified Modeling Language (UML) adalah sebuah "bahasa" yang telah menjadi standar dalam industri untuk visualisasi, merancang dan mendokumentasikan sistem piranti lunak."

Ada beberapa diagram yang disediakan dan dapat digunakan dalam unified Modelinf Languange $(U M L)$, yaitu sebagai berikut:

a. Use Case Diagram

Use case diagram merupakan pemodelan untuk menggambarkan kelakuan (behavior) sistem yang akan dibuat. Diagram use case mendeskripsikan sebuah interaksi antara satu atau lebih aktor dengan sistem yang akan dibuat.

Untuk penjelasan mengenai simbol use case diagram dapat dilihat pada tabel 2.3.

b. Sequence Diagram

Sequence Diagram menggambarkan kelakuan/perilaku objek pada use case dengan mendeskripsikan waktu hidup objek dan message yang dikirim dan diterima antar objek. Banyaknya diagram sequence yang harus digambarkan adalah sebanyak pendefinisian use case yang memiliki proses sendiri. Untuk penjelasan mengenai simbolactivity diagram dapat dilihat pada tabel 2.4

c. Activity Diagram

Diagram aktivitas atau activity diagram menggambarkan workflow (aliran kerja) atau aktivitas dari sebuah sistem atau proses bisnis. Diagram aktivitas menggambarkan aktivitas sistem bukan apa yang dilakukan aktor. Untuk penjelasan mengenai simbol activity diagram dapat dilihat padatabel 2.5. d. Class Diagram

Diagram kelas menggambarkan struktur sistem dari segi pendefinisian kelas-kelas yang akan dibuat untuk membangun sistem. Kelas memliki apa yang disebut dengan atribut dan metode atau operasi. Untuk penjelasan mengenai simbol class diagram dapat dilihat padatabel 2.6.

e. Collaboration Diagram

Serupa dengan diagram rangkaian/sekuensi, tetapi tidak fokus pada timing atau sekuensi pesan. Diagram ini justru menggambarkan interaksi (kolaburasi) antara objek dalam sebuah format jaringan.

f. Statechart Diagram

Diagram ini digunakan untuk memodelkan behavior objek khusus yang dinamis. Diagram ini mengilustrasikan siklus hidup objek-berbagai keadaan yang dapat diasumsikan oleh objek dan event-event (kejadian) yang menyebabkan objek beralih dari satu state ke state lain.

g. Component Diagram

Digunakan untuk menggambarkan organisasi dan ketergantungan komponen-komponen software sistem. Komponen diagram dapat digunakan untuk menunjukkan bagaimana kode pemrograman dibagi menjadi modul-modul (komponen).

h. Deployment Diagram

Digunakan untuk mendeskripsikan arsitektur fisik dalam istilah "mode" untuk hardware dan software dalam sistem. Diagram ini menggambarkan konfigurasi komponenkomponen software realtime, prosesor, dan peralatan yang membentuk arsitektur sistem.

\subsection{Zachman Framework}

Berdasarkan

http://12650081si.blogspot.com/2014/04/artikel-zachman-

framework.html maka Zachman Framework merupakan suatu alat bantu yang dikembangkan untuk memotret arsitektur organisasi dari berbagai sudut pandang dan aspek, sehingga didapatkan gambaran organisasi secara utuh [2]. Zachman framework, dikeluarkan oleh Zachman Institut for Framework Advancement [5] sebagai hasil pemikiran dari John Zachman [3]. Framework ini merupakan framework arsitektural yang paling banyak dikenal dan diadaptasi dan memberikan gambaran yang lengkap dan menetapkan nama yang unik untuk setiap sel dalam framework. Zachman Framework merupakan logika terstruktur untuk pengklasifikasian dan pengorganisasian tipe-tipe dokumen, rancangan atau model yang merepresentasikan sebuah 
Kristina. Pemodelan Sistem Informasi Pendataan Warga Dan Biaya Operasional Lingkungan

Pada Komplek Perumahan HarmoniPark Berbasis Zachman Framework

perusahaan. Zachman Framework bukan metodologi untuk mengembangkan suatu arsitektur enterprise. Zachman Framework bersifat kategorisasi artefak Enterprise Architecture. Zachman Framework hanya berupa thingking tool yang membantu arsitek dan manajer mengisolasikan masalah dan mengatur apa saja yang perlu diurus.

Pengembangan system dalam Zachman Framework hampir sama dengan yang lain tetapi lebih terorganisir:

1. Strategi - Perencanaan dari suatu usaha pengembangan sistem keseluruhan organisasi.

2. Analisa - Definisi yang terperinci tentang persyaratan untuk area tertentu dari bisnis tersebut.

3. Rancangan - Penerapan teknologi yang spesifik [bagi/kepada] persyaratan menggambarkan selama analisa.

4. Konstruksi - Konstruksi yang nyata dari sistem tersebut.

5. Dokumentasi - Persiapan dari manual pemakai, pedoman, dan lain lain menguraikan sistem tersebut.

6. Transisi - Implementasi dari sistem, agar supaya menjadi bagian dari infrastruktur organisasi tersebut.

7. Produksi - pengecekan berkelanjutan dari sistem, untuk memastikan bahwa sistem tersebut memenuhi kebutuhan dari organisasi.

\section{HASIL DAN PEMBAHASAN}

Setelah didapat data dan informasi melalui wawancara dan observasi, maka langkah selanjutnya adalah melakukan pemetaan permasalahan dengan tujuan untuk mendapatkan hasil rancangan sistem yang diinginkan. Kemudian setelah permasalahan dipetakan, langkah selanjutnya akan dilakukan penyusunan permasalahan yang ada.

\subsection{Perspektif Planner}

Perspektif sering disebut dengan arsitektur kontekstual. Arsitektur ini mendefinisikan model bisnis fungsional secara global dan berbagai kebutuhan diluar organisasi. merencanakan penetapan objek yang dibahas, latar belakang, ruang lingkup dan tujuan enterprise sistem informasi. Baris ini sering disebut baris konteks.

a) Data (what)

Kolom what ini menyajikan data-data dari perspektif planner. Data-data tersebut diantaranya data warga, data iuran, dan data upload bukti iuran, dan data laporan. Data warga terdiri dari nomor identitas warga, nomor kartu keluarga, nomor KTP, nama, alamat beserta RT dan RW nya.

b) Function (how)

Kolom how ini mejelakan proses-proses pendataan warga dan iuran bulanan warga di komplek perumahan Harmoni Park. Proses tersebut antara lain bagaimana proses pendataan tersebut dilaksanakan. Bagaimana cara melakukan pembayaran iuran warga menggunakan website yang akan dibangun?

c) Network (where)

Kolom where ini menjelaskan posisi atau lokasi keberadaan komplek perumahan Harmoni Park. Lokasi berada di Kota Baru Pontianak.

d) People (who)

Pada kolom who ini menjelaskan sumber daya manusia (SDM) yang berperan penting terhadap sistem informasi pendataan warga dan iuran. Adapun SDM tersebut diantaranya, Ketua, Sekretaris, Bendahara RT, dan Warga.

e) Time (when)

Pada kolom when ini menjelaskan mengenai waktu atau jadwal pendataan warga, perubahan data warga, dan input data iuran bulanan, serta upload bukti pembayaran iuran.

f) Motivation (why)

Kolom why ini menjelaskan tentang pendataan warga yang efektif, dan laporan keuangan RT yang transparan.

\subsection{Perspektif Owner}

Perspektif owner merupakan sudut pandang dari sisi pemilik atau yang bertanggung jawab terhadap organisasi. Sudut pandang ini menjabarkan mengenai usulan sistem informasi, yang mana usulan sistem informasi ini dapat digunakan dengan gambaran yang sederhana, dan dapat berjalan dengan bantuan teknologi informasi yang ada pada saat sekarang ini.

a) Data (what)

Kolom ini memberikan penjelasan bagaimana cara entitas yang sudah ditetapkan pada sudut pandang Planner berhubungan dalam mengoperasikan proses pada sistem informasi pendataan warga dan iuran. Berikut ini digambarkan dalam bentuk ERD untuk hubungan antar data-data tersebut, berikut ini 


$$
\begin{array}{r|l}
\text { Jurnal Sains Komputer dan Teknologi Informasi } & \text { Page } \\
\text { e-issn: 2655-7460. Volume } 2 \text { No.1, November 2019 } & 55-62
\end{array}
$$

\begin{tabular}{|c|c|}
\hline \multirow{4}{*}{$\begin{array}{l}\text { Warga } \\
\text { +Id_Warga } \\
+ \text { +No_KTP } \\
+ \text { No_KK } \\
+ \text { +Nama } \\
+ \text { Alamat } \\
\text { +RT } \\
+ \text { +RW }\end{array}$} & \\
\hline & \multirow{2}{*}{\begin{tabular}{|c|c|}
\multicolumn{1}{|c}{ Iuran } \\
+ Id_TIx \\
+TIIITIx \\
+Nominal
\end{tabular}} \\
\hline & \\
\hline & \\
\hline & Laporar \\
\hline Upload & +Tgl_Tix \\
\hline $\begin{array}{l}\text { Idd-Upload } \\
\text { +Dokumen }\end{array}$ & $\begin{array}{l}\text { +Debet } \\
\text { +Kredit }\end{array}$ \\
\hline
\end{tabular}

adalah

Gambar 1. Rincian Informasi Hubungan Antar Data

\section{b) Function (how)}

Kolom ini menggambarkan dan menjelaskan proses interaksi antara aktor-aktor dengan proses dalam sistem. Interaksi antara aktor dengan proses digambarkan dengan usecase diagram. Berikut ini gambar yang menunjukkan interaksi antara aktor dengan proses pada sistem yang akan dibangun.

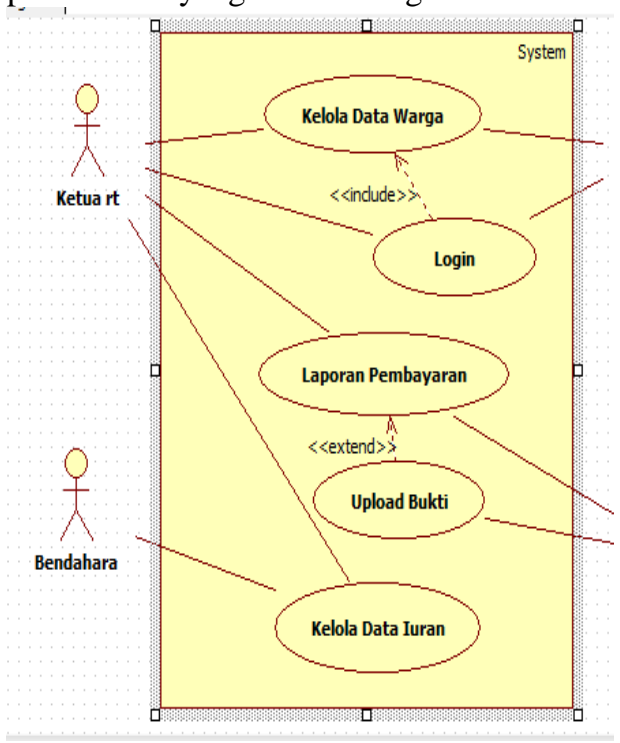

Gambar 2. Use Case Diagram Sistem Informasi yang Akan Dibangun

Berikut ini adalah uraian prosedur sistem baru yang di usulkan:

a) Login

Ketua RT maupun sekretaris diminta melakukan login menggunakan username dan password yang telah tersedia. Setelah melakukan login, Ketua RT atau sekretaris akan dihadapkan pada halaman berikutnya yaitu halaman kelola data warga.

b) Kelola Data Warga

Pada proses ini mengelola data warga hanya dapat dilakukan oleh ketua RT bersama dengan sekretaris dikarenakan untuk mengantisipasi apabila terjadi sesuatu yang tidak diinginkan. Data yang dimaksud dalam data warga ini adalah meliputi data diri warga seperti nomor identitas warga, nomor Kartu Tanda Peduduk (KTP), Nomor Kartu Keluarga, Nama warga, alamat beserta RT dan RW dari warga tersebut.

\section{c) Upload Bukti}

Pada proses ini warga diminta wajib mengupload bukti bahwa telah melakukan pembayaran iuran sebelum melakukan laporan. Selain melakukan upload bukti pembayaran, warga juga diminta mengupload data diri apabila belum terdaftar sebagai warga pada komplek tersebut.

Apabila sudah terdaftar maka halaman tersebut hanya akan menampilkan untuk proses upload bukti pembayaran.

\section{d) Laporan Pembayaran}

Pada proses ini apabila warga telah mengupload bukti pembayaran nya maka halaman ini menampilkan pemberitahuan mengenai warga yang sudah membayar ataupun melaporkannya. Kemudian laporan tersebut akan di terima oleh ketua $\mathrm{rt}$ yang kemudian akan diproses dan kemudian data tersebut akan di sampaikan kepada bendahara.

\section{e) Kelola Data Iuran}

Pada proses ini data tentang warga yang telah melakukan pembayaran iuran tersebut akan di serahkan ketua rt kepada bagian bendahara yang kemudian akan dikelola oleh bendahara.

c) Network (where)

Kolom where ini menjelaskan mengenai lokasi yang akan dijadikan tempat untuk sistem informasi. Sistem informasi pendataan warga dan iuran ini akan ditempatkan pada jaringan internet, diharapkan informasi dapat diakses dari diakses oleh warga dimanapun dan kapanpun. Begitupun dalam proses pencatatan dan monitoring iuran dapat dilakukan kapanpun dan dimanapun berada. 
Kristina. Pemodelan Sistem Informasi Pendataan Warga Dan Biaya Operasional Lingkungan

Pada Komplek Perumahan HarmoniPark Berbasis Zachman Framework

d) People (who)

Pada kolom who ini menjelaskan sumber daya manusia (SDM) yang ditugaskan dalam proses pengelolaan data di dalam sistem. Adapun SDM tersebut yaitu Sekretaris dan Bendahara RT. Tugas masing-masing bendahara dan sekertaris ini seperti mengelola data iuran warga beserta mengelola data dari warga komplek itu sendiri.

e) Time (when)

Pada kolom when ini menjelaskan mengenai jadwal atau time schedule untuk membangun sistem informasi pendataan warga dan iuran, yang mana jadwal tersebut ditentukan oleh pihak owner, setelah jadwal disusun kemudian jadwal tersebut akan didelegasikan kepada tim yang akan melaksanakan pembangunan sistem informasi atau dalam hal ini adalah pihak yang akan mengerjakan proyek.

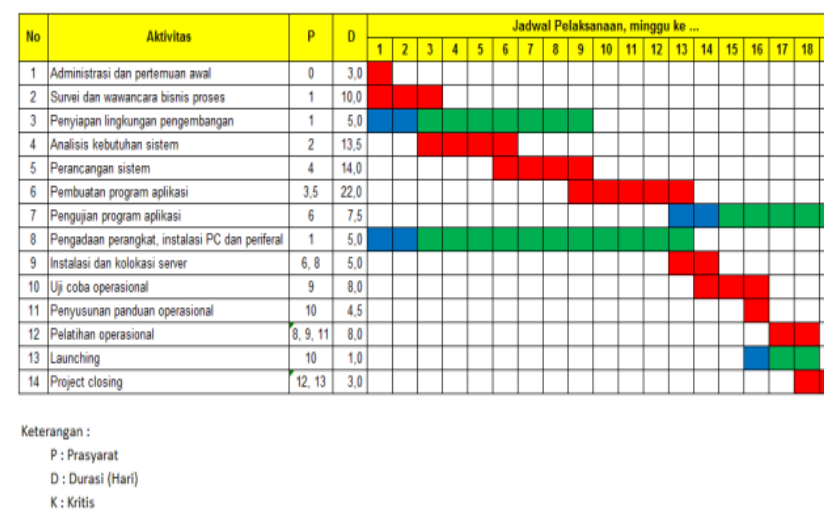

Gambar 3. Jadwal Perencanaan Proyek (Time Schedule)

f) Motivation (why)

Kolom why ini menjelaskan tentang pendataan warga yang efektif, dan laporan keuangan RT yang transparan. Kolom whyini akan menjelaskan tujuan dan harapan yang ingin dicapai terkait dengan pembangunan sistem informasi. Adapun tujuannya yaitu: a) Membuat administrasi data warga dalam hal proses pengelolaan dan penyimpanan data dapat terorganisir dengan baik, b) Membuat laporan keuangan kas warga yang lebih transparan, c) Memanfaatkan teknologi informasi dalam membangun, dan mengoperasikan sistem informasi, sehingga pengelolaan data lebih cepat, tepat dan akurat.

\section{KESIMPULAN}

Mengacu pada pembahasan yang sudah dipaparkan diatas, dapat ditarik beberapa kesimpulan, yaitu:

a) Pemodelan sistem informasi dengan menggunakan Zachman Framework membantu analis melihat sistem secara lebih detil dan luas. Tujuannya agar analis dapat membangun sistem informasi yang tepat sasaran.

b) Pemodelan sistem informasi ini memberikan gambaran yang jelas dalam mengelola pendataan warga dan iuran bulanan warga, serta gambaran sistem secara utuh dan detail dari perspektif planner dan owner,

c) Hasil pemodelan membantu meminimalisasi biaya pengembangan sistem informasi pendataan dan biaya operasional pada Kompleks Perumahan Harmoni Park.

\section{SARAN}

Sedangkan ada beberapa saran agar dalam pengembangan aplikasi seperti ini dapat dilakukan dengan optimal dan tepat sasaran, diantaranya yaitu:

a) Penelitian ini hanya mengacu ke perspektif Planner dan Ownersaja, tapi diharapkan untuk penelitian pengembangan sistem informasi ini selanjutnya dapat mengacu kepada seluruh perspektif yang ada.

b) Ini masih merupakan rancangan awal, pihak internal perumahan dapat mengembangkan kembali rancangan ini menjadi yang lebih baik. Sehingga dalam pencatatan dan laporan hasil iuran dapat lebih terstruktur dan bersifat transparansi.

c) Pemodelan sistem informasi diharapkan dapat menjadi dasar perancangan dan pembangunan sistem informasi pendataan warga dan biaya operasional pada Kompleks Perumahan Harmoni Park.

\section{DAFTAR PUSTAKA}

1) William Chang. (2017).Metodologi Penulisan Ilmiah. Penerbit Erlangga, Jakarta

2) Anggraeni, ElisabetYunaetidan Rita Irviani. (2017). PengantarSistemInformasi. CV Andi Offset. Yogyakarta. 


$$
\begin{array}{c|l}
\text { Jurnal Sains Komputer dan Teknologi Informasi } & \text { Page } \\
\text { e-issn: 2655-7460. Volume 2 No.1, November 2019 } & 55-62
\end{array}
$$

3) Yakub. (2012). PengantarSistemInformasi. Grahallmu. Yogyakarta.

4) Hutahaen, Jeperson. (2014). Konsep Sistem Informasi. Deepublish. Yogyakarta.

5) Tohari, hanim. (2014). Analisis dan Perancangan Sistem Informasi Melalui Pendekatan UML. Andi. Yogyakarta.

6) Sutabri, tata. (2012). Analisis Sistem Informasi. Andi. Yogyakarta.

7) http://12650081-

si.blogspot.com/2014/04/artikel-zachmanframework.html
8) Djahir, Yulia. (2014). Bahan Ajar Sistem Informasi Manajemen. Deepublish. Yogyakarta.

9) Mulyani, Sri. (2016). Metode Analisis dan Perancangan Sistem. Abdi Sistematika. Bandung

10) Departemen Pendidikan Nasional( 2008) Kamus Besar BahasaIndonesia Pusat Bahasa EdisiKeempat. Jakarta: GramediaPustaka Utama. 